\title{
Reverse engineering of metabotropic glutamate receptor-dependent long-term depression in the hippocampus
}

\author{
Tim Tambuyzer ${ }^{1}$, Tariq Ahmed ${ }^{2}$, Daniel Berckmans ${ }^{1}$, Detlef Balschun², Jean-Marie Aerts ${ }^{1 *}$ \\ From Twentieth Annual Computational Neuroscience Meeting: CNS*2011 \\ Stockholm, Sweden. 23-28 July 2011
}

This study focused on metabotropic glutamate receptordependent long-term depression (mGluR-LTD) in the hippocampus. This form of LTD is suggested to play a key role in learning, memory and the plasticity of behaviour. Recent advances have started to uncover the underlying mechanisms of mGluR-LTD [1]. However, it is not completely clear how these mechanisms are linked and it is believed that several crucial mechanisms still remain to be revealed.

The two main objectives of this study were (i) to quantify the dynamics of mGluR-LTD responses by dynamic data-based models and (ii) to identify underlying dominant processes of mGluR-LTD by applying mathematical system identification methods. In recent years, more and more researchers advocate the use of a top-down modelling approach (reverse engineering) for improving the knowledge of biological systems $[2,3]$.

The drug dihydroxyphenylglycine (DHPG) was used to induce mGluR-LTD in rat brain slices (table 1). The drug was applied for different durations (5min, 15min, 2 hours) and in different concentrations ( $15 \mathrm{mM}, 30 \mathrm{mM})$. In addition, also different sampling intervals (5min, 30s, 90s) were used.

For the modelling, discrete-time Transfer Functions (TF) models were used. The models described the relation between the DHPG application (input) and the long-term depression responses (output).
All models were very accurate $\left(\right.$ all $\mathrm{R}_{\mathrm{T}}{ }^{2}$-values higher than 0,94 ) and reliably estimated. For a 2 hours application of $30 \mu \mathrm{M}$ DHPG sampled with a frequency of $1 /$ 30 s, the time-constant of the mGluR-LTD response was 92s. Thus, the models for high sampling rate indicated that a sampling interval of 30 s would be ideal to minimize information loss of the dynamics of mGluR-LTD responses.

Interestingly, it was suggested that there are three dominant sub-processes underlying mGluR-LTD: one fast sub-process, one slow sub-process and an immediate sub-process.

This study suggests that the dynamic data-based modelling approach can be a valuable tool for reverse engineering of mGluR-dependent LTD responses.

Table 1 Overview of the experiments

\begin{tabular}{|c|c|c|c|c|c|}
\hline Dataset & $\begin{array}{l}\text { DHPG } \\
\text { concentration } \\
(\mu \mathrm{M})\end{array}$ & $\begin{array}{l}\text { Duration of } \\
\text { DHPG input }\end{array}$ & $\begin{array}{l}\text { Sampling } \\
\text { rate }\end{array}$ & $\begin{array}{l}\text { Age } \\
\text { rats }\end{array}$ & $\begin{array}{l}\text { Number of } \\
\text { repetitions }\end{array}$ \\
\hline 1 & 15 & $5 \mathrm{~min}$ & $1 / 300 \mathrm{~s}$ & $\begin{array}{l}\text { 7-8 } \\
\text { weeks }\end{array}$ & 4 \\
\hline 2 & 15 & $15 \mathrm{~min}$ & $1 / 300 \mathrm{~s}$ & $\begin{array}{l}\text { 7-8 } \\
\text { weeks }\end{array}$ & 32 \\
\hline 3 & 15 & $15 \mathrm{~min}$ & $1 / 30 \mathrm{~s}$ & $\begin{array}{l}\text { 10-11 } \\
\text { months }\end{array}$ & 14 \\
\hline 4 & 30 & $15 \mathrm{~min}$ & $1 / 300 \mathrm{~s}$ & $\begin{array}{l}8 \\
\text { weeks }\end{array}$ & 10 \\
\hline 5 & 30 & $15 \min$ & $1 / 30 \mathrm{~s}$ & $\begin{array}{l}14 \\
\text { months }\end{array}$ & 8 \\
\hline 6 & 30 & $15 \mathrm{~min}$ & $1 / 90 \mathrm{~s}$ & $\begin{array}{l}15 \\
\text { months }\end{array}$ & 4 \\
\hline \multirow[t]{2}{*}{7} & 30 & $2 \mathrm{~h}$ & $1 / 30 \mathrm{~s}$ & $\begin{array}{l}10-11 \\
\text { months }\end{array}$ & 9 \\
\hline & & Total nu & nber of ex & eriments: & 81 \\
\hline
\end{tabular}

\footnotetext{
* Correspondence: jean-marie.aerts@biw.kuleuven.be 'Department of Biosystems, M3-BIORES: Measure, Model and Manage Bioresponses, Katholieke Universiteit Leuven, Leuven, B-3001, Belgium Full list of author information is available at the end of the article
} 


\section{Author details}

'Department of Biosystems, M3-BIORES: Measure, Model and Manage Bioresponses, Katholieke Universiteit Leuven, Leuven, B-3001, Belgium.

${ }^{2}$ Department of Psychology, Laboratory for Biological Psychology, Katholieke Universiteit Leuven, Leuven, 3000, Belgium.

Published: 18 July 2011

\section{References}

1. Luscher C, Huber K: Group 1 mGluR-dependent synaptic long-term depression: mechanisms and implications for circuitry and disease. Neuron 2010, 65(4):445-459.

2. Csete M, Doyle JC: Reverse engineering of biological complexity. Science 2002, 295:1664-1669.

3. Tomlin CJ, Axelrod JD: Understanding biology by reverse engineering the control. Proceedings of the National Academy of Sciences of the United States of America 2005, 102(12):4219-4220.

doi:10.1186/1471-2202-12-S1-P1

Cite this article as: Tambuyzer et al: Reverse engineering of metabotropic glutamate receptor-dependent long-term depression in the hippocampus. BMC Neuroscience 2011 12(Suppl 1):P1.

\section{Submit your next manuscript to BioMed Central} and take full advantage of:

- Convenient online submission

- Thorough peer review

- No space constraints or color figure charges

- Immediate publication on acceptance

- Inclusion in PubMed, CAS, Scopus and Google Scholar

- Research which is freely available for redistribution

Submit your manuscript at www.biomedcentral.com/submit 